\title{
NON-LINEAR ANALYSIS OF INFILLED FRAMES
}

\author{
Niranjan C.B. ${ }^{1}$, M. V Renukadevi ${ }^{2}$, K.S.Jagadish ${ }^{3}$ \\ ${ }^{1}$ PG Student, ${ }^{2}$ Associate Professor, PG Studies, ${ }^{3}$ Professor, PG Studies, Department of Civil Engineering, R.V.College of \\ Engineering, Bengaluru-560059 \\ niranjancb@rediffmail.com,renu_gowri@yahoomail.com,ksjagadish@gmail.com
}

\begin{abstract}
Unreinforced masonry in fills has long been known to affect the strength and stiffness of frame. Under the action of a lateral load the principal compressive diagonal acts as a strut or bracing and increases the initial lateral stiffness of the framed structure. However, in the presence of openings in walls, which is more practical, the behavior of infill changes. The primary objective of this paper is to study the variation of lateral stiffness, principal compressive diagonal strut width with modulus of masonry infill, with and without openings. In the study a non-linear (multi-linear) analysis is performed, since it is more realistic. From the analysis performed using ANSYS Version 10.0 it is seen that linear analysis over-estimates the lateral stiffness of the infill frame. Further, it is observed that the width of compressive diagonal generally decreases with increase in the modulus of masonry. It is also seen that incase of two frames with equal area of openings, the frame with larger width of opening exhibits slightly more initial lateral stiffness due to possibility of formation of single diagonal strut.
\end{abstract}

Key words: Infill frame, principal compressive diagonal, initial lateral stiffness, equivalent strut width, multi-linear analysis.

\section{INTRODUCTION}

Unreinforced masonry construction is one of the oldest construction techniques used for over centuries. In the present, masonry has been more commonly used in framed buildings as infill where it is intended to cover the area within the frames or act as partition walls and is not considered structural. Hence, the common practice has been to ignore the infill during the analysis and design of steel or concrete frame structures. However, infill wall tend to interact with the surrounding frame when the structure is subjected to wind or earthquake loads; the resulting system is referred to as an infilled frame.

In seismic areas, the frame infill panel interaction cannot be ignored because under a lateral load an infill in an infilled frame structure separates from the frame near the leeward side (unloaded corner) at top and at the bottom corner near the loaded side. The infill then behaves as a compressive diagonal strut connecting the two loaded corners, acting as a strut or bracing and dramatically increasing the initial lateral stiffness of the infill-frame composite structure[1].Thus, contributing to the overall strength and stiffness of the structure. On the other hand, it is to be noted that the contribution of the infill to the lateral stiffness of the structure is reduced when subjected to earthquake loads (reversed cyclic loadings) when they are subjected to large non-linear cycles of loading [2] and also by the presence of openings in the infill walls which is inevitable. Modeling the behavior of infill frame is a complex issue because the structure exhibits a highly non-linear response as a result of the masonry infill panel and surrounding frame interaction. This interaction essentially depends on the interface conditions, whether integral or non-integral or the presence of gaps between the masonry infill and the surrounding frame. The highly brittle and uncertain properties of the masonry materials further add to the problem [2].

The aim of this paper is to investigate the variation of lateral stiffness of brick masonry infilled reinforced concrete frame with different opening sizes and varying modulus of masonry. a single bay, single storey infill frame is chosen for the analysis. In order to model the behavior of the structure in a more realistic way, the materials i.e., concrete, mortar and masonry prisms are tested for their physical and mechanical properties and their corresponding stress-strain behavior is adopted in the analysis.

\section{THE METHOD OF ANALYSIS}

The finite element analysis technique developed by Asteris (2003)[3,4] is adopted to study the behavior of infill frames under lateral loads. The basic characteristic of the analysis is that the frame infill contact lengths are calculated and are not assumed by using an empirical formula.

\subsection{Finite Element Model}

The analysis is carried out using ANSYS version 10.0. A 3-D Elastic Beam4 element is used to model the frame elements. The masonry infill wall is modeled using a 4-noded plane stress element, Plane42. Finally the interface between the frame and masonry infill is modeled by using tension/compression only link element, Link8. 


\subsection{Procedure for Analysis}

The analysis procedure can be summarized into the following steps:

- Modeling of frame, infill and the interface using the above mentioned elements.

- Assigning corresponding properties to the elements.

- Applying the load and assigning the constraints.

- Solving the problem.

- After solving the problem, the nodal forces in the link elements are checked. only compression only link elements are retained and the problem is solved again.
- The above step is repeated until the forces in the link elements are compressive.

\subsection{Input Parameters}

The model used by Goutam Mondal and Jain [5] is adopted for the analysis. The properties of the models and materials are given below in Table 1. The modulus of elasticity and compressive strength and other mechanical properties are obtained by testing in laboratory.

Table 1: Properties of the model elements

\begin{tabular}{|c|c|c|c|c|}
\hline Elements & $\begin{array}{c}\text { Modulus of } \\
\text { Elasticity (MPa) }\end{array}$ & $\begin{array}{c}\text { Poisson's } \\
\text { ratio }\end{array}$ & $\begin{array}{c}\text { Compressive } \\
\text { Strength (MPa) }\end{array}$ & Dimensions (mm) \\
\hline Masonry Infill 1 & 698 & 0.18 & 1.54 & $5000 \times 3000 \times 225$ \\
\hline Masonry Infill 2 & 1067 & 0.18 & 3.34 & $5000 \times 3000 \times 225$ \\
\hline Masonry Infill 3 & 1450 & 0.18 & 2.06 & $5000 \times 3000 \times 225$ \\
\hline Masonry Infill 4 & 4034 & 0.18 & 3.2 & $5000 \times 3000 \times 225$ \\
\hline Beam & 48540 & 0.2 & 27 & $230 \times 400$ \\
\hline Column & 48540 & 0.2 & 27 & $400 \times 400$ \\
\hline Link & 25967 & 0.2 & 7.05 & \\
\hline
\end{tabular}

The stress-strain curves for the materials used for multi-linear analysis are shown Fig. 1 below:

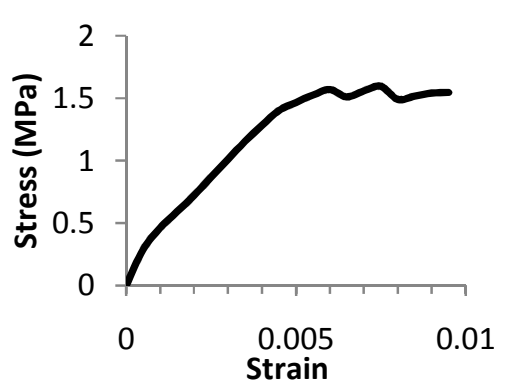

(a)

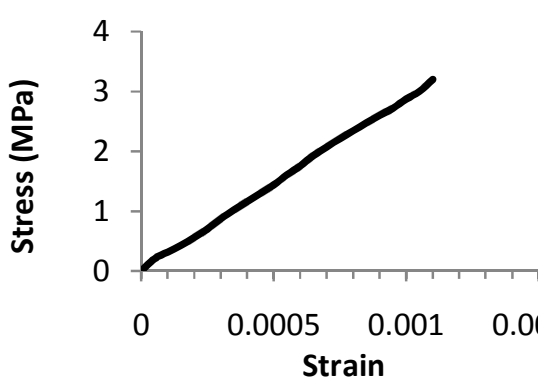

(d)

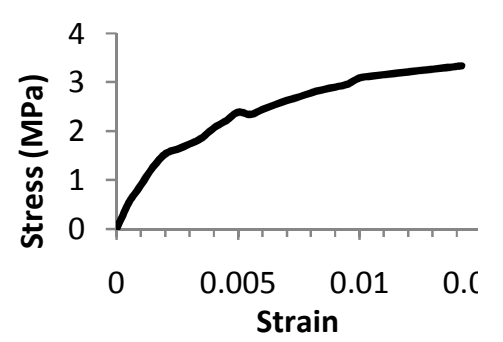

(b)

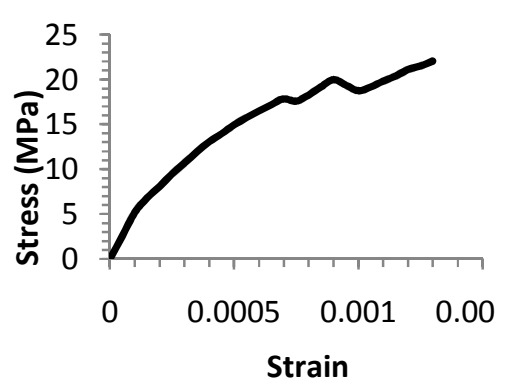

(e)

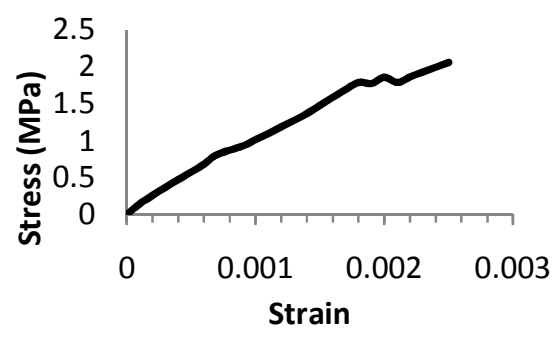

(c)

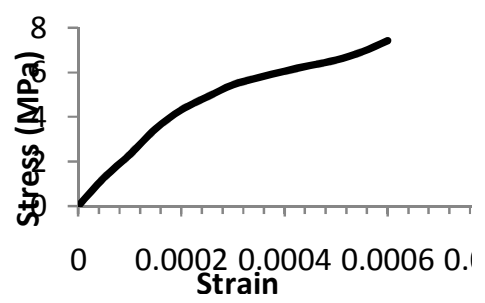

(f)

Fig. 1: Stress-Strain Curves for (a) Masonry Infill, Em= $698 \mathrm{Mra}$; (b)Masonry Infill, Em=1067 MPa ; (c) Masonry Infill, Em=1450 $\mathrm{MPa}$; (d) Masonry Infill, Em= $4034 \mathrm{MPa}$; (e) M20 Concrete, E=48540MPa ; (f) 1:6 Cement: Mortar, E=25967MPa. 


\section{ANALYTICAL INVESTIGATION}

Reinforced concrete infill frame with four different types of solid masonry infill having different modulus of elasticity of masonry was analyzed. The Fig. 2 below shows the variation of third principal stress in infill frame with masonry modulus of $698 \mathrm{MPa}$. The lateral stiffness values obtained on

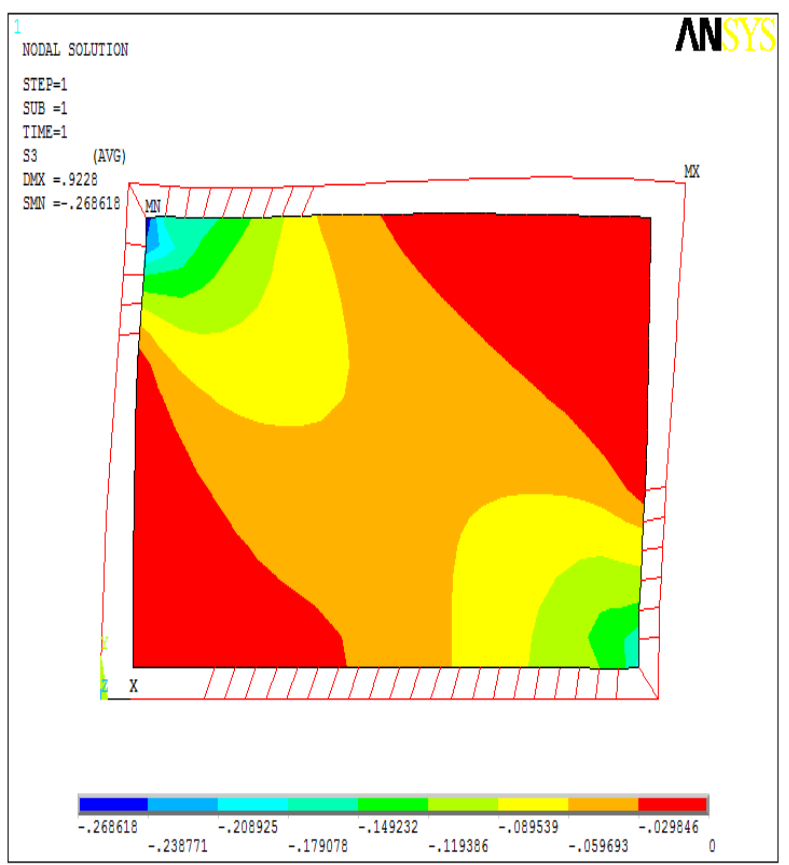

performing linear analysis (constant value of Elastic modulus of masonry, Em) is found to be lower than that obtained by non-linear (or multi-linear) analysis. The difference for the four infill frames varies by about $6-11 \%$ indicating that linear analysis over-estimates the lateral stiffness compared to multilinear analysis.

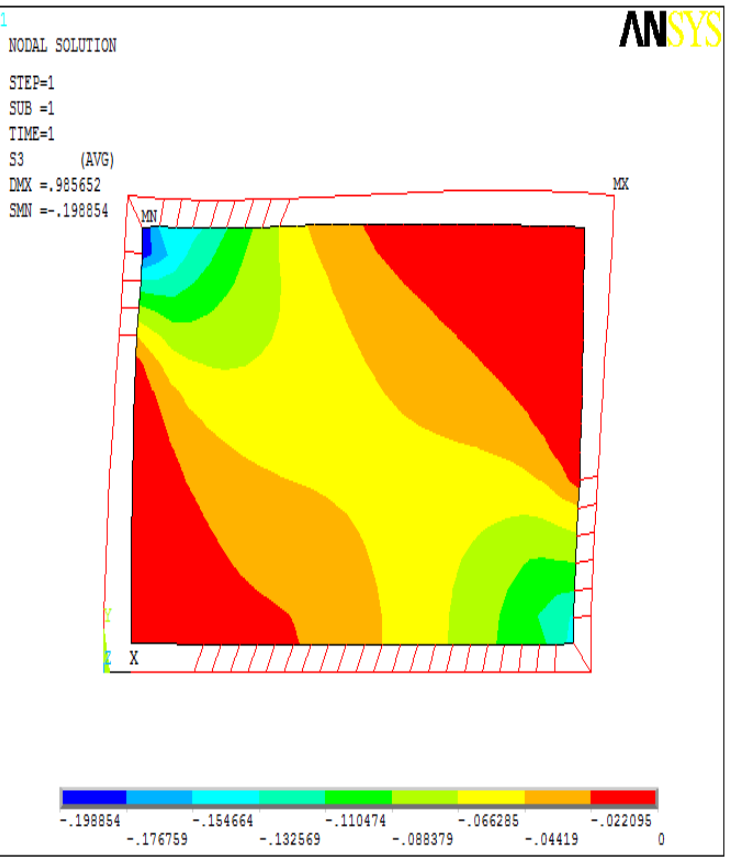

Fig 2: Variation of third principal stress in infill frame with modulus of masonry of 698MPa.

\subsection{Effect of Opening Size on the Initial Lateral}

\section{Stiffness of Infilled Frame}

In order to study the behavior of infill frame and variation of lateral stiffness with opening and modulus of masonry, a parametric study is carried out for different widths of opening, with varying heights and modulus of masonry. For, a particular modulus of masonry the width of opening was assumed to be $500 \mathrm{~mm}$ and the height of opening was varied as $500,1000,1500$ and $2000 \mathrm{~mm}$ and the lateral stiffness was obtained. Similarly, different widths of openings as 1000 , 1500 and $2000 \mathrm{~mm}$ are adopted and the lateral stiffness is obtained.

Initial lateral stiffness's determined by non-linear finite element analysis for varying modulus of masonry is plotted in Fig. 3 below. In the figure the width and height of opening are normalized with respect to width and height of infill respectively, and lateral stiffness of infill- frames is normalized with respect to lateral stiffness of fully infilled frame. 


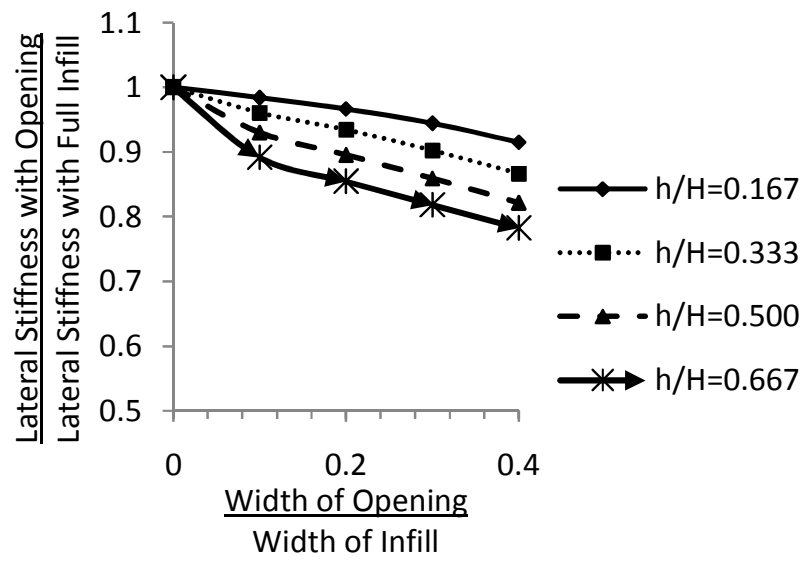

(a)

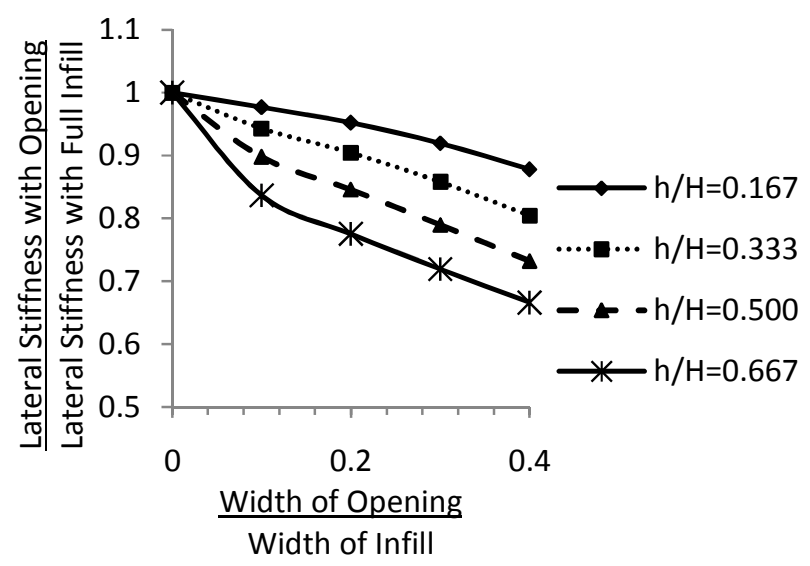

(c)

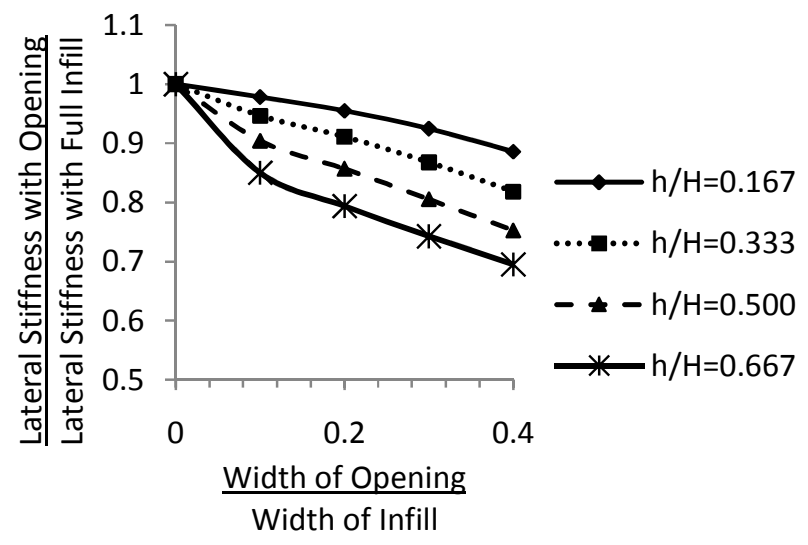

(b)

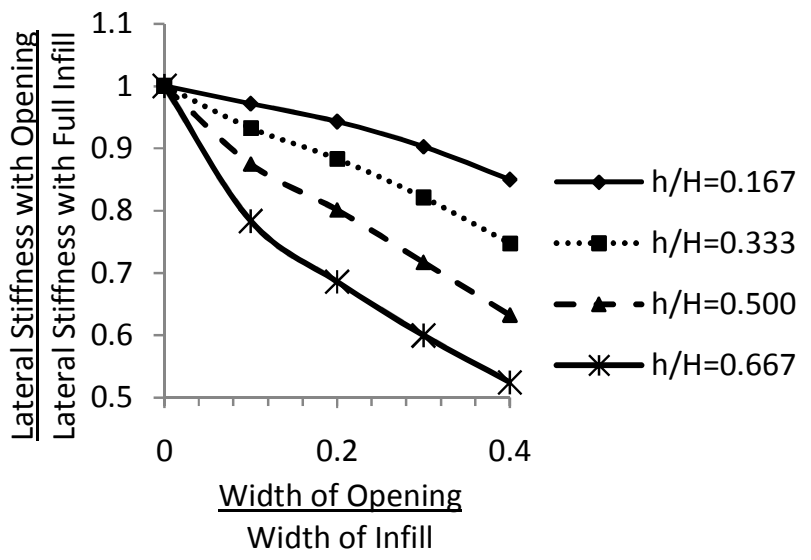

(d)

Fig. 3: Variation of Initial Lateral Stiffness with different modulus of masonry (a) Em=698 MPa; (b) Em=1067 MPa ; (c) Em=1450 $\mathrm{MPa} ;$ (d) Em=4034 Mpa

\section{Observations on initial lateral stiffness of infilled}

\section{frame}

From the above plots it can be observed that: (a) presence of opening significantly reduces the initial lateral stiffness of infilled frame; (b) the reduction in initial lateral stiffness when compared to a solid infilled frame is $21,30,34$ and $48 \%$ for infill frames with modulus of masonry as $698 \mathrm{MPa}, 1067 \mathrm{MPa}$, $1450 \mathrm{MPa}$ and $4034 \mathrm{MPa}$ respectively; (c) higher the modulus of masonry of infill higher will be the loss in initial lateral stiffness with increase in opening size.

\subsection{Effect of Dimensions of Opening}

In order to study the effect of dimensions of openings, infill frames with equal areas of openings but different dimensions of openings are analyzed. Table 2 shows the variation of initial lateral stiffness for infill walls with two modulus of masonry 698MPa and 4034MPa. 
Table 2: Effect of dimension of opening on initial

\begin{tabular}{|c|c|c|c|c|c|c|c|c|c|}
\hline \multicolumn{5}{|c|}{ Elastic Modulus of Masonry= $698 \mathrm{MPa}$} & \multicolumn{5}{|c|}{ Elastic Modulus of Masonry=4034MPa } \\
\hline \multicolumn{2}{|c|}{$\begin{array}{c}\text { Width smaller than } \\
\text { Height }\end{array}$} & \multicolumn{2}{|c|}{$\begin{array}{c}\text { Width larger than } \\
\text { Height }\end{array}$} & \multirow{2}{*}{$\begin{array}{c}\text { Difference } \\
(\%)\end{array}$} & \multicolumn{2}{|c|}{$\begin{array}{c}\text { Width smaller than } \\
\text { Height }\end{array}$} & \multicolumn{2}{|c|}{$\begin{array}{c}\text { Width larger than } \\
\text { Height }\end{array}$} & \multirow{2}{*}{$\begin{array}{c}\text { Difference } \\
(\%)\end{array}$} \\
\hline $\begin{array}{c}\text { Opening } \\
\text { Size }(\mathbf{m m} \mathbf{x} \\
\mathbf{m m})\end{array}$ & $\begin{array}{c}\text { Lateral } \\
\text { Stiffness } \\
(\mathrm{kN} / \mathrm{mm})\end{array}$ & $\begin{array}{c}\text { Opening } \\
\text { Size }(\mathbf{m m} \mathbf{x} \\
\mathbf{m m})\end{array}$ & $\begin{array}{c}\text { Lateral } \\
\text { Stiffness } \\
(\mathrm{kN} / \mathrm{mm})\end{array}$ & & $\begin{array}{c}\text { Opening } \\
\text { Size }(\mathrm{mm} \mathbf{x} \\
\mathrm{mm})\end{array}$ & $\begin{array}{c}\text { Lateral } \\
\text { Stiffness } \\
\text { (kN/mm) }\end{array}$ & $\begin{array}{c}\text { Opening } \\
\text { Size }(\mathrm{mm} x \\
\mathrm{mm})\end{array}$ & $\begin{array}{c}\text { Lateral } \\
\text { Stiffness } \\
\text { (kN/mm) }\end{array}$ & \\
\hline $500 \times 1000$ & 51.949 & $1000 \times 500$ & 52.255 & 0.585 & $500 \times 1000$ & 126.175 & $1000 \times 500$ & 127.535 & 1.066 \\
\hline $500 \times 1500$ & 50.283 & $1500 \times 500$ & 51.054 & 1.509 & $500 \times 1500$ & 118.331 & $1500 \times 500$ & 122.094 & 3.082 \\
\hline $500 \times 2000$ & 48.235 & $2000 \times 500$ & 49.489 & 2.534 & $500 \times 2000$ & 105.974 & $2000 \times 500$ & 114.936 & 7.797 \\
\hline $1000 \times 1500$ & 48.411 & $1500 \times 1000$ & 48.810 & 0.817 & $1000 \times 1500$ & 108.369 & $1500 \times 1000$ & 111.059 & 2.422 \\
\hline $1000 \times 2000$ & 46.227 & $2000 \times 1000$ & 46.878 & 1.388 & $1000 \times 2000$ & 92.794 & $2000 \times 1000$ & 101.146 & 8.258 \\
\hline $1500 \times 2000$ & 44.269 & $2000 \times 1500$ & 44.417 & 0.332 & $1500 \times 2000$ & 81.148 & $2000 \times 1500$ & 85.614 & 5.215 \\
\hline
\end{tabular}

\section{Observations on effect of dimension of opening}

The following observations are made on the effect of dimensions of opening on the lateral stiffness of infilled frame: (a) for the same area of opening if the dimensions of opening vary, the difference in lateral stiffness is generally less than $10 \%$; (b) for the same area of opening the frame with larger width of opening exhibits higher lateral stiffness, because of the formation of a single diagonal struts as the panels considered for analysis are rectangular. As the height of opening increases the panel is divided into two sub-panels which increase the possibility of formation of multi-strut as shown in Fig 4 below.
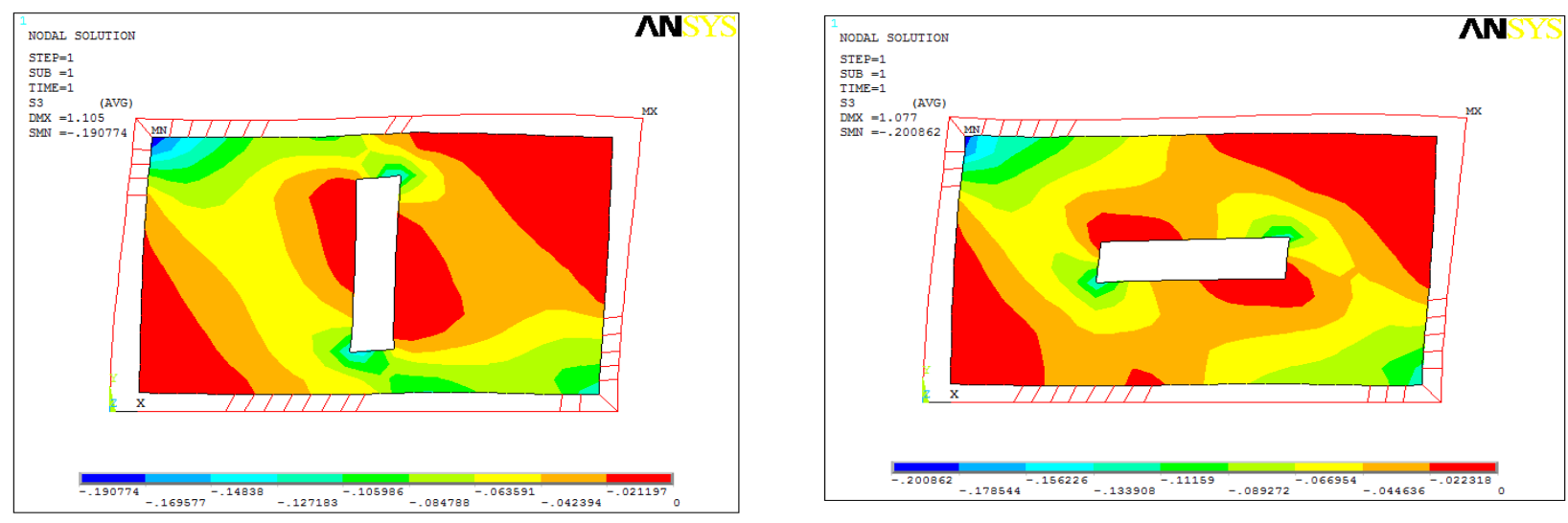

Fig. 4: Variation of compression diagonal strut in infill framed structure

\subsection{Effect of Modulus of Masonry on Principal}

\section{Compressive Diagonal (strut width)}

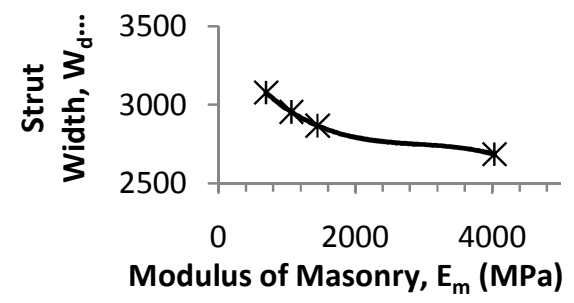

Fig. 5: shows the variation of width of principal compressive diagonal with modulus of masonry.
Observation: From the plot it can be seen that the average width of the principal compressive diagonal decreases with increasing modulus of masonry and the infill behaves more like a strut/bracing.

\section{CONCLUSIONS}

From the non-linear or multi-linear analysis of a single-bay, single storey infilled frame, the following conclusions can be obtained:

- Linear analysis over-estimates the initial lateral stiffness and thus the lateral forces coming onto the structure. It does not take into account the strength degradation of 
infill with loading. Non-linear analysis on the other hand is more realistic and accurate.

- Higher the modulus of masonry, higher will be the loss in initial lateral stiffness with increasing area of opening.

- For the same area of opening, if the dimensions are varied, the difference in initial stiffness is less than $10 \%$. The frame with larger width of opening than the height exhibits slightly increased initial lateral stiffness than a infill frame with larger height of opening.

- The area of opening is the main factor affecting the initial lateral stiffness of infilled frame and not the height/width (aspect ratio) of opening.

- As the modulus of masonry is increased the width of principal compressive diagonal decreases.

\section{REFERENCES}

[1] El-Dakhakhni, W. W., Elgaaly, M., and Hamid, A. A. (2003). "Three-strut model for concrete masonryinfilled frames.” Journal of Structural Engineering, Vol. 129(2), pp. 177-185.

[2] P. G. Asteris, M.ASCE, S. T. Antoniou, D. S. Sophianopoulos, M.ASCE, and C. Z. Chrysostomou, "Mathematical Modelling of Infilled Frames: State of the Art", Journal of Structural Engineering, 137, pp. 1508-1517, December 2011.

[3] P.G. Asteris, "A New Method of Analysis of Masonry Infilled Frames", SEWC Yokohama, Japan, T1-2-c-3.

[4] P.G. Asteris, "Lateral Stiffness of Brick masonry Infilled Plane Frames", Journal of Structural Engineering, 129(8), pp. 1071-1079.

[5] Goutam Mondal and Sudhir K. Jain, " Lateral Stiffness of Masonry Infilled Reinforced Concrete Frames with Central Openings", Earthquake Spectra, Vol.23, No.3, pp. 701-723, August 2008

[6] Stafford Smith B (1962), " Lateral stiffness of infilled frames" Journal of Structural Division, Proceedings of the American Society of Civil Engineers, Vol. 88, No. ST 6, December 1962, pp. 183-199.

[7] Hashemi, A., and Mosalam, K. M. (2006). "Shake-table experiment on reinforced concrete structure containing masonry infill wall." Earthquake Eng. Struct. Dyn., 35(14), 1827-1852.

[8] A. Madan, A.M. Reinhorn, J.B. Mander, R.E. Valles (1997), "Modeling of Masonry Infill Panels for Structural Analysis ", Journal of Structural Engineering, Vol. 123, No. 10, October 1997, pp. 1295-1302.

[9] Roger D. Flanaganand Richard M. Bennett (2001), "InPlane Analysis of Masonry Infill Materials", Practice Periodical on Structural Design and Construction, Vol. 6, No.4, November 2001, pp. 176-182.

[10] Ashok K. Ghosh and Amde M. Amde (2002), "Finite Element Analysis of Infilled Frame" Journal of Structural Engineering, Vol. 128(2), July 2002, pp. 881889. 